\title{
Regular Students Attitude toward Students with Special Educational Needs: A Comparative Study in Inclusive Private and Public Primary Schools
}

\author{
Rafidah Riahta, Farida Kurniawati \\ Faculty of Psychology \\ Universitas Indonesia \\ Depok, Indonesia \\ rriahta@gmail.com
}

\begin{abstract}
The aim of this study was to the comparative attitude of regular students toward the students with Special Educational Needs (SEN) based on inclusive private and public primary schools. The quantitative research method was selected for collecting data for the study. 266 students from several schools were involved in this research. In order to answer the research question of this study, the attitude of the students was measured using Chedoke-McMaster Attitudes Towards Children with Handicaps (CATCH) by Rosenbaum (1988) and had been adapted with good reliability $(0,7)$. CATCH consists of 18 items which includes 3 dimensions of attitude (knowledge, affect and behavior). Data collection took place in the classrooms in November 2017. The result showed that there is a significant difference in attitude score between students from inclusive public primary schools $(M=47.6, S D=5.2)$ and students from inclusive private primary schools $(M=46.01, S D=4.47)$; $t(264)=2.56, p<0.05$. This study reveals that regular students' knowledge about the students with SEN is a possible reason to explain differences in attitude score between students from inclusive private and public primary schools. These findings also suggest future researcher to consider measurement tools to examine the attitude of regular students toward students with SEN.
\end{abstract}

Keywords-attitude, inclusive education, primary school, students with sen.

\section{INTRODUCTION}

Individuals with disabilities are those who have long-term physical, intellectual, mental or sensory limitations (UU No. 8 tahun 2016 tentang Penyandang Disabilitas). In the context of education, individuals with disabilities are usually defined as students with Special Educational Needs (SEN). Students with SEN are defined as students who need special education and services that are relevant to their kind of special educational needs [1].

Currently, there are $18 \%$ of 1.6 million students with SEN have received education in inclusive schools [2]. An inclusive school is one of the schools that can provide opportunities for students with SEN to get an education equivalent to regular students in the same class [3]; Hallahan \& Kauffman, 2006). Nowadays, the government tries to continue increasing the number of inclusive schools and building physical facilities for students with SEN.

Based on previous study' result, the students with SEN can get many benefits from inclusive school. The good relationship with regular students made students with SEN more confident, brave and open [4]. The students with SEN have the motivation to increase their communication skill, negotiation and academic performance [5] - [9]. Meanwhile, regular students also get a chance to improve their social development. Regular students get a chance to help students with SEN to develop academic and social skills [10]. It means inclusive educational setting has benefits for students with SEN as well as regular students.

However, research has shown that some students with SEN may experience the challenges of acceptance from regular students. Students with SEN usually have low social participation in class than regular students [11]. Furthermore, the social participation of students with SEN depends on the willingness of regular students to accept and interact with them [12], [13]. One of the relevant factors to make students with SEN experience challenges in establishing relationships with regular students is the attitude of the regular students toward students with SEN.

Attitude is individual' reaction toward an issue, despite favorable or unfavorable. In this study, attitude consists of three components such as cognitive, affective and behavioral intention (Triandis, 1971). Cognitive consists of an individual's belief about the 'object'. Within the context of attitude toward students with SEN, cognitive component of an attitude can show with "I wouldn't mind if students with SEN sits next to me". Affective component refers to feelings about the 'object'. Within the context of attitude toward students with SEN, affective component of attitude can show with "I feel sorry for students with SEN".Behavioral component is someone's predisposition to act toward the 'object'. Within the context of attitude toward students with SEN, behavioral component of attitude can show with "I would invite students with SEN to my house".

Regular students' who had a positive attitude toward students with SEN will spend more time in the classroom with students with SEN [13] and interacted more often with 
students with SEN in free play activity [10]. The attitude of regular students toward students with SEN will affect regular students' peer acceptance [10] and the friendship of regular students and students with SEN. This condition is relevant to the children's social development. At that age, children begin to establish wider relationships besides family [14]. This condition makes the attitude of the regular students toward students with SEN is an important thing for implementing inclusive primary schools.

Based on the previous study, it was revealed that regular students had a negative attitude toward the students with SEN [15], [16]. Regular students' knowledge about the students with SEN is an important factor to form the attitude of the regular students toward students with SEN. The regular students who had enough knowledge about the students with SEN will reduce their misunderstanding and feeling of pity to students with SEN [6]. However, the regular students in inclusive education rarely get access to know about the students with SEN. This condition makes the regular students depend on their experience on the class to form their attitude toward students with SEN.

The regular students' experience with students with SEN usually depends on school' policies, such as support arrangements [13], [16] and facilitating socialization [13]. Support arrangements directly affect the quality of academic, social learning opportunities of students with SEN and also influencing the regular students' perception form about students with SEN [16]. Support arrangements, such as classroom climate or classroom management will give chance to regular students interacting with the students with SEN. Good support arrangement which provided to students and planned by the teacher has a great impact on students with SEN. However, support arrangements in this school depend on teachers' attitude toward students [13], [17], [18] and school' policy.

In Indonesia, the school' policy about inclusive education in inclusive private and public primary schools have a different process. In inclusive public primary schools, services for students with SEN or inclusive education' policy are mandated by the educational government. Meanwhile, inclusive education' policy in inclusive private primary schools was decided by the headmaster [19]. This condition affects school' policy to prepare the inclusive program in their school, such as school facilities, teacher, fund or the number of students with SEN for each class [20], [21].

In inclusive public primary schools, school's policy about inclusive education will depend on government' program about inclusive education [21]. In inclusive public primary schools, the number of students with SEN for each class usually 3-5 students with SEN and teacher usually does not know about the kind of SEN for each student. Socialization about the inclusive program for students and teacher also depend on government' policy. Meanwhile, in inclusive private primary school, headmaster's thoughts about inclusive education or students with SEN affect the inclusive education implementation in that school [21]. The inclusive private primary school usually requires the students with SEN parents to bring assessment result from psychology before the students with SEN attend their class. Therefore, this present study tries to unravel the attitude of regular students from inclusive private and public primary schools toward the students with SEN. The hypothesis of this study is there are differences attitude between the students from inclusive private and public primary schools toward students with SEN

\section{METHOD}

This study applied comparative research. In order to answer the research question, five schools were assigned to be participants in this study. This study was conducted in November 2017 in 5 schools consisting of 3 inclusive public primary schools and 2 inclusive private primary schools. These schools were selected for the study because they already become inclusive schools for years and accepting student with SEN in every class. There are 266 students who participate in this study involving 113 students from inclusive public primary school and 153 students from the inclusive private primary school in Depok and Jakarta. All of the participants were from the 3 rd to the 5 th grade.

The measurement tool used in this study was ChedokeMcMaster Attitudes Towards Children with Handicaps (CATCH). CATCH consisted of 18 items which include 3 dimensions of attitude (knowledge, affect and behavior). Students were asked their level of agreement with statements by 4 -point Likert scale ( $1=$ totally disagree to $4=$ totally agree). CATCH had good reliability $(0,7)$ and was tested on 266 students in inclusive primary school. Data collection took place in the classrooms in November 2017. Questionnaires were distributed to the students and took 20 minutes to fill them in. This study is descriptive which aims to the comparison of the students' attitude toward the student with SEN based on demographic data such as the kind of school they from. The Independent Sample T-test is used to find out the significance of the mean difference between the two sample groups.

\section{RESUlt AND DiscuSSION}

TABLE I. MEAN SCORE OF BOTH GROUPS

\begin{tabular}{|l|l|l|l|l|}
\hline & School & N & \multicolumn{1}{|c|}{ Mean } & Std. Deviation \\
\hline \multirow{2}{*}{ RS } & Public & 113 & 47.5752 & 5.18378 \\
\cline { 2 - 5 } & Private & 153 & 46.0196 & 4.47283 \\
\hline
\end{tabular}

Based on the independent sample T-test' result, it reveals that there are significant differences on the attitude of the students from inclusive public primary schools $(M=47,58$, $\mathrm{SD}=5,18)$ and the attitude of students from inclusive private primary schools $(\mathrm{M}=46,02, \mathrm{SD}=4,47) ; \mathrm{t}(264)=5,62, \mathrm{p}<.05$. It means the alternative hypothesis is accepted by this result. It also indicated that regular students' from inclusive private and public primary school have a neutral attitude toward the students with SEN.

This study aims to answer the research problem about the attitude of the regular students in inclusive private and public primary schools toward the students with SEN. Based on the results of the study, it is revealed that there are significant differences in the attitude of regular students from inclusive private and public primary schools. The results of this study 
explain that external factors, such as the type of school also affect the attitude of regular students toward students with SEN. In general, the regular students in inclusive private and public primary schools have a neutral attitude toward the students with SEN. These results also show that the attitude of regular students toward the students with SEN in inclusive public primary schools is better than the attitude of regular students for students with SEN in inclusive private primary schools. These results are in line with the previous studies related to the form of the attitude of the regular students that usually analyze the influence of regular students' internal factors, such as age and gender toward the attitude of regular students.

The results of this study indicate that the regular students from inclusive private and public primary schools have a neutral attitude toward students with SEN. This is different than the results of the previous study which stated that regular students tend to have a negative attitude toward students with SEN [15], [16], [21]. The previous study revealed that students with SEN experience the challenges of acceptance from regular students have low social participation in class than regular students [11] and low interact with regular students [12], [13]. Therefore, the results of this study stating that regular students have a neutral attitude to students with SEN are expected to provide opportunities for students with SEN to be accepted by regular students in friendship and to participate more in classroom activities[10], [13]. This result is also expected to support students with SEN' social development.

Besides that, the main reason that seems to affect differences on the attitude of the students from inclusive private and public primary school is the influence of stigma associated with students with SEN in the regular students. The stigma is formed by the regular students' knowledge about the students with SEN and makes them aware of the meaning and characteristics of students with and also their experiences of interacting with students with SEN [6]. This happens to the regular students in inclusive private primary schools. The socialization conducted by the teacher makes the regular students aware of the presence of students with SEN at school. This knowledge might influence the stigma of regular students toward students with SEN in inclusive private primary schools. This finding is different than the results of previous studies which stated that socialization related to special educational needs will foster a positive attitude of the regular students toward students with SEN [6], [7], [13], [22], [23], [24]. This is also a consideration for future researchers to further analyze the influence of supporting programs given to regular students on the inclusive private primary school.

This condition is different from the regular students in inclusive public primary schools. The inclusive public primary schools that became the participant in this study had never conducted socialization about students with SEN to regular students. It seems to make the regular students not understand the meaning, characteristics, and influence of special educational needs on students with SEN. Regular students tend to think that students with SEN are same as other regular students. This is also seen in observations when collecting data. Regular students several times ask questions related to issue about students with SEN and claimed they do not know their classmates who had SEN. This lack of knowledge makes the regular students in inclusive public primary schools not associate school facilities that supporting inclusive programs, the number of students with SEN, the attitude of teachers toward students with SEN with special educational needs issues. This seems the reason for the different results related to the effect school types on the attitude of students with SEN in previous research and this study.

The results of this study are different compared to the results in previous studies. In several previous studies, differences in school characteristics are considered to influence the attitude of the students toward the students with SEN. These differences can be seen in the number and characteristics of students with SEN who received at the school [23], [25] and school support for inclusion programs in these schools [22], [24], [25].

In Indonesia, the number of students with SEN in inclusive public primary schools usually more than inclusive private primary schools [20]. In previous studies, the number and type of SEN that students with SEN have will affect the attitude of regular students toward students with SEN [8], [10]. Based on interviews with the teacher in inclusive public primary schools, there is no specific policy related to the number or type of SEN that students with SEN had. Meanwhile, In inclusive private primary schools, schools apply policies to students with SEN to collect psychological assessments when registering at school. In addition, the kind of SEN in inclusive private primary schools dependent on the school's policy.

In this study, the number of students and the types of characteristics of students with SEN might do not affect the attitude of regular students toward the students with SEN. It seems to be related to the condition of the regular students in inclusive public primary schools who do not understand the type and number of students with SEN in their classrooms. They also might not aware that their classmate had a SEN. The incomplete information makes regular students consider students with SEN as same as other regular students. This condition makes a chance to students with SEN accepted by regular students and have more participation in the classroom [10], [12].

Furthermore, the attitude of the teachers in inclusive public primary schools showed by teachers' treat to the students with SEN as same as regular students and it also influences students' knowledge about any issues related to special educational needs. The attitude of the teachers toward students with SEN is an important element that influences the attitude of the regular students toward students with SEN [13], [17]. It is related to the teacher who is considered as a role model for the regular students in inclusive primary schools [9], [11]. In addition, attitudes of teachers will influence student interaction in class and classroom management [9], [25].

Based on previous research, there are differences in the attitude of the teachers toward inclusive education in inclusive private and public primary schools [19], [20]. The differences in attitudes of teachers are seen in the way the teacher manages the class [19]. Teachers' interaction in inclusive public primary schools has not shown a positive attitude 
toward students with SEN [22]. Teachers in inclusive public primary schools do not involve the regular students to assist students with SEN in class and often ignore the needs of students with SEN in their classrooms [19]. This is in contrast to the inclusive private primary schools teachers who involve regular students to assist students with SEN and manage the classroom by considering the needs of students with SEN had [19]. In this study, the attitude of teachers in schools related to students with SEN cannot be identified quantitatively. However, the attitude of teachers in inclusive public primary schools who tend to pay less attention to the needs of students with SEN and treat students with SEN as same as regular students seems to make regular students not link these attitude to the issue of students with SEN.

The results of this study also refer to school's support, such as school facilities to inclusive education programs which will influence the attitude of the regular students toward students with SEN. School facilities are designed to support the implementation of inclusive programs, such as socialization or supporting facilities for inclusive programs [16]. In this study, inclusive private primary schools that are the subjects of the research have special mentoring teachers for each student with SEN, give socialization related to inclusive programs, the existence of individual educational plans and other supporting accessibility. This condition makes the regular students had knowledge about students with SEN. This result was also revealed in Purbani's study on 2013 which stated that there is the willingness of inclusive private primary schools to create an inclusive program effectively.

Meanwhile, inclusive public primary schools that are subject to this research do not have adequate supporting facilities. Inclusive public primary schools have not provided special mentoring teachers for students with SEN, inadequate accessibility and had never conducted adequate socialization related to inclusive programs for the regular students. In addition, the school rarely suggests parents of students with SEN attend the psychological examination. This makes the needs of students with SEN not yet known with certainty. This condition supports Purbani's research in 2013 which states that the appointment of inclusive public primary schools as inclusive public primary schools by the government cannot be carried out properly by the school. It illustrates the differences in facilities provided by kind of schools and seems to influence the attitude of students toward students with SEN. However, the results of this study indicate that external factor, such as kind of the school, the facilities in schools or the number and the kind of do does not seem to be the only factor that influences the attitude of the regular students toward students with SEN. This can be shown by the attitude of regular students in inclusive public primary schools more positively than the attitude of regular students in inclusive private primary schools.

Regarding the limitations of this study, further researchers are suggested to consider the use of self-report measuring instruments. The use of this measuring instrument tends to be less able to describe the attitude of regular students toward students with SEN in daily life. In addition, this measuring instrument has a high social desirable. Therefore, the further researcher is expected to conduct observations and interviews.
Furthermore, it is suggested for the further researcher to analyze several factors that influence the attitude toward students with SEN, both internal and external factors. This is expected to provide a clearer explanation of the attitude of regular students toward students with SEN.

\section{CONCLUSION}

The results of this study are expected to provide information about students' attitude toward students with SEN based on demographic data, such as kind of school. The information from this study can be a suggestion for government or headmasters' to make the inclusive school's policy.

\section{REFERENCES}

[1] F. Mangunsong, Psikologi Pendidikan Anak Berkebutuhan Khusus (Jilid 1). Depok: Lembaga Pengembangan Sarana Pengukuran dan Pendidikan Psikologi UI (LPSP3 UI), 2014.

[2] D. Maulipaksi, "Sekolah Inklusi dan Pembangunan SLB Dukung Pendidikan Inklusi," Kementrian Pendidikan dan Kebudayaan, 2017. [Online]. Available: https://www.kemdikbud.go.id/main/blog/2017/02/ sekolah-inklusi-dan-pembangunan-slb-dukung-pendidikan-inklusi. [Accessed: Sept. 1, 2018].

[3] Republic of Indonesia. Undang-Undang Republik Indonesia No. 80 tahun 2016 tentang Penyandang Disabilitas, Jakarta: Sekretariat Negara, 2016.

[4] L. N. Wauters and H. Knoors, "Social Integration of Deaf Children in Inclusive Settings," Journal of Deaf Studies and Deaf Education, vol. 13, no. 1, pp. 21-36, 2008

[5] A. Capodlecl, T. Rivetti, and C. Cornoldi, "A Cooperative Learning Classroom Intervention for Increasing Peer's Acceptance of Children with ADHD," Journal of Attention Disorder, pp. 1-11, 2016.

[6] A. A. De Boer, S. J. Pijil, and A. Minnaert, "Evaluating the Effectiveness of an Intervention Program to Influence Attitudes of Students Towards Peers with Disabilities," Journal Autism Dev Disord, vol. 44, no. 3, pp. 572-583, 2014.

[7] B. Doll, P. Murphy, and S. Y. Song, "The relationship between children's self-reported recess problems, and peer acceptance and friendship," Journal of School Psychology, vol. 41, pp. 113-130, 2002.

[8] C. Hurst, K. Corning, and R. Ferrante, "Children's Acceptance of Others with Disability: The Influence of Disability-Simulation Program," J Genet Counsel, vol. 21, no. 6, pp. 873-883, 2012.

[9] N. Kiuru, K. Aunola, M.-K. Lerkkanen, E. Pakarinen, E. Poskiparta, T Ahonen, A.-M. Poikkeus, and J.-E. Nurmi, "Positive teacher and peer relations combine to predict primary school students' academic skill development.," Developmental Psychology, vol. 51, no. 4, pp. 434-446, Apr. 2015.

[10] K. Petry, "The Relationship between Class Attitudes towards Peers with a Disability and Peer Acceptance, Friendships, and Peer Interactions of Students with a Disability in Regular Secondary Schools," European Journal of Special Needs Education, vol. 33, no. 2, pp. 254-268, 2018.

[11] E. Avramidis, "Social relationships of pupils with special educational needs in the mainstream primary class: peer group membership and peer-assessed social behaviour," European Journal of Special Needs Education, vol. 25, no. 4, pp. 413-429, Nov. 2010.

[12] G. Laws and E. Kelly, "The Attitudes and Friendship Intentions of Children in United Kingdom Mainstream Shools towards Peers with Physical or Intellectual Disabilities," International Journal of Disability, Development, and Education, vol. 52, no. 2, pp.79-99, 2015.

[13] J. Lequia, "Social Acceptance of Students with Significant Disabilities by General Education Peers in Inclusive Elementary School Settings,' Doctoral dissertation, The University of Wisconsin-Madison, Madison, Winconsin, United States, 2015

[14] J. W. Santrock, Educational Psychology. Dallas: University of Texas, 2010 . 
[15] A. Olayeye, O. Ogundele, S. Deji, O. Ajayi, O. Olayeye, and T. Adeyanju, "Attitudes of Students towards Peers with Disability in an Inclusive School in Nigeria," Disability, CBR \& Inclusive Development, vol. 23, no. 3, pp. 65-75, 2012.

[16] N. Smith, "The face of disability in Nigeria: a disability survey in Kogi and Niger States," Disability, CBR \& Inclusive Development, vol. 22, no. 1, pp. 35-47, 2011.

[17] A. Garrote and R. S. Dessemontet, "Social Participation in Inclusive Classrooms: Empirical and Theoretical Foundations of an Intervention Program," Journal of Cognitive Education and Psychology, vol. 14, no. 3, pp. 3375-388, 2015.

[18] H. Avcloglu, "Classroom Teachers Behaviors and Peers Acceptance of Students in Inclusive Classrooms," Educational Sciences: Theory \& Practice, vol. 17, no. 2, pp. 463-492, 2017.

[19] W. Purbani, "Equity in the Classroom: The System and Improvement of Inclusive Schools in Yogyakarta, Indonesia (A Case Study)," US-China Education Review B, vol. 3, no. 7, pp. 507-518, 2013.

[20] C. M. Sihombing and F. Kurniawati, "Hubungan antara Sikap terhadap Pendidikan Inklusif dan Strategi Pengajaran pada Guru SD Negeri
Inklusif dan SD Swasta Inklusif,” Thesis, Universitas Indonesia, West Java, Indonesia, 2014

[21] S. S. Taylor, "Special Education and Private Schools: Principals' Points of View," Remedial and Special Education, vol. 26, no. 5, pp. 281-296, 2005.

[22] G. Greene, "Teacher's Attitude toward Inclusive Classrooms," Doctoral dissertation, Walden University, Minnesota, United States, 2017.

[23] M. Schmidt and K. Vrhovnik, "Attitudes of teachers towards the inclusion of children with special needs in primary and secondary schools," Hrvatska revija za rehabilitacijskaistraživanja, vol. 51, no. 2, pp. 16-30, 2015.

[24] H. Tsakiridou and K. Polyzopoulou, "Greek Teachers' Attitudes toward the Inclusion of Student with Special Educational Needs." American Journal of Educational Research, vol. 2, no. 4, pp. 208-218, 2014.

[25] S. Elisa and A. T. Wrastari, "Sikap Guru terhadap Pendidikan Inklusi Ditinjau dari Faktor Pembentuk Sikap," Jurnal Psikologi Perkembangan dan Pendidikan, vol. 2, no. 1, pp. 1-10, 2013. 